The 9 th International Graduate Students and Scholars' Conference in Indonesia (IGSSCI) SUSTAINING THE PLANET: A CALL FOR INTERDISCIPLINARY APPROACHES AND ENGAGEMENT

Graduate School, Universitas Gadjah Mada,August, 9 - 10, 2017 ,Yogyakarta-Indonesia

\title{
MASS MEDIA AND GREEN AIRPORT IN INDONESIA: DO THEY AWARE OF SMART VILLAGE?
}

\author{
Andika SANJAYA ${ }^{1}$ Hardi ALUNAZA ${ }^{2}$ Taufik HIDAYAH ${ }^{3}$ Suswandoyo BIYOGA ${ }^{4}$ \\ ${ }^{1}$ Doctoral School in Politics, Diponegoro University, Central Java. \\ ${ }^{2}$ Department of International Relations, Tanjungpura University, West Kalimantan. \\ ${ }^{3}$ Department of Historical Sciences, Diponegoro University, Central Java. \\ ${ }^{4}$ Department of Communication Sciences, University of Indonesia, West Java. \\ E-mail: andikasanjaya@student.undip.ac.id
}

\begin{abstract}
Nowadays, the concept of the smart city has been a monumental issue. There are many factors of a smart city to be accomplished by the governments. One of the notable factors is the smart environment. The governments must make the policies that fully support the green city life. Instead of replicating the smart city concept, Banyuwangi Regency has gone up into the spotlight as a smart village innovator in Indonesia. In 2017, the Regent has finished Blimbingsari Airport terminal, a terminal with the green concept. The green airport is a main gate for the domestic and international tourists, supporting eco-tourism. The airport is also the example of the smart mobility implementation. Any government policy will always need the publication of mass media. By using content analysis, we identify what media talk about the green airport. The media ignore the smart village topic related to the airport, choosing to focus on the tourism and its architecture. They talk positively about the green airport but need to be directed to the smart village grand design. However, when time files, the leader changes, we urge the vision stays.
\end{abstract}

Keywords: Smart city, smart village, smart environment, smart mobility, ecotourism, media research.

\section{INTRODUCTION}

\section{- Background}

The city governments in the world face urban agglomeration as a threat. People keep coming to the city to find a better living. According to a research from United Nations, the percentage of the urban population will be increased up to 66 percent by the year 2050 . The urbanization may be a threat or an opportunity, it depends on the readiness of the government. The crime, disease, and the poverty are three examples of the urban problems (United Nations, 2014).

Knowing the problems, the city governments must be smart enough. There is a metaphor that an industrial city has a skeleton and skin. Meanwhile, a smart city has an artificial nervous system. It links all the parts of the body mimicking a 
Graduate School, Universitas Gadjah Mada,August, 9 - 10, 2017 ,Yogyakarta-Indonesia

human system. The smart city concept is taken into credit as a solution of the urban problems (Nam \& Pardo, 2011).

There are many concepts related to the smart city, divided by three dimensions. The first dimension is technology, the related concepts are the digital city, intelligent city, ubiquitous city, wired city, hybrid city, and the information city. The second dimension is people, the related concepts are the creative city, learning city, humane city, and the knowledge city. The last dimension is the community, it only consists of a smart community. The smart city summarizes all of the concepts (Nam \& Pardo, 2011).

The smart city is a vision which consists of the smart transportation, smart environment, smart healthcare, smart safety, smart education, and the smart energy (Nam \& Pardo, 2011). There are other characteristics of a smart city which covers the smart economy, smart people, smart governance, smart mobility, smart environment, and the smart living (Giffinger et al, 2007). Both characteristics contain the smart environment while the smart transportation is a synonym of the smart mobility. The two concepts which are used in this study.

To accomplish the smart city vision, the government must handle the institutional factors (governance), technology factors (integration), and the human factors (learning) (Nam \& Pardo, 2011). However, according to Effendi and his colleagues (2016), the smart city implementation needs a collaboration between the government, the university, the business, the community, and the media. Also, the local wisdom must be considered to develop a smart city.

Sanjaya and his colleagues have pointed the facts that the government, the university, and the business joined the collaboration by doing research. Yuliarti and her colleagues (2016) showed the role of the media to develop the smart city in the national context. Here, we want to inquiry the role of the media, especially in the local context.

\section{- Smart Village of Banyuwangi}

If we talk about the smart city in Indonesia, Bandung is the most popular case. According to a research from Sanjaya and his colleagues (2017), Bandung tops the rank of research locations of the smart city in Indonesia. Bandung is included into the list of 25 cities which has been a national pilot project of smart cities by The Ministry of Communication and Information Technology.

However, the research body about the other cities is still inadequate. There are only 13 out of 39 locations in Indonesia which have been the research locations. Banyuwangi is an example, the city is only mentioned as a research location by Effendi and his colleagues (2016). By considering the status of Banyuwangi as a national pilot project, a research about the city must be necessary (Sanjaya et al, 2017).

Banyuwangi government is the current contender of smart city innovator in Indonesia. Instead of copying the mainstream style of the smart city like Bandung, Banyuwangi government chooses to pick the different way. The regent of 
The 9 th International Graduate Students and Scholars' Conference in Indonesia (IGSSCI) SUSTAINING THE PLANET: A CALL FOR INTERDISCIPLINARY APPROACHES AND ENGAGEMENT

Graduate School, Universitas Gadjah Mada,August, 9 - 10, 2017 ,Yogyakarta-Indonesia

Banyuwangi Abdullah Azwar Anas has spoken the truth that Banyuwangi regency ignores the similarity with Bandung smart city (Banyuwangi Government, 2016a).

Banyuwangi government implements smart village vision named "Smart Kampung", rather than chooses a smart city. The reasons are the different condition and resource between the city and the village. In Bandung, the government has the decent infrastructure and also the well-educated human resource, the resources which Banyuwangi doesn't have on the same stage (Banyuwangi Government, 2016a).

The Smart Kampung program has been started since 2016 by having seven criteria. The criteria are public service, economic empowerment, health service, educational and cultural development, the improvement of human resource capacity, integrated poverty alleviation, and information literacy of law. The government uses ICT to accomplish the criteria (Banyuwangi Government, 2016a).

In 2016, about 41 out of 176 villages in Banyuwangi regency has been the pilot project of the ambitious smart village. By using technology, the villages are integrated so the villagers can join in collaborative development (Banyuwangi Government, 2016a).

We can compare Banyuwangi with LaGrange, a small remote village located in Georgia, United States. By having only 26.000 populations, the village can transform into a smart village which has been financially sustained by running the internet-based business (Intelligent Community Forum, 2017).

\section{- Smart Village, Tourism, and Media}

In 2017, Banyuwangi completes the terminal construction of the airport named "Blimbingsari". Blimbingsari airport is a gate for the national and international visitors. The terminal has been claimed that it has the different concept with the other terminals in Indonesia. The terminal boasts its green concept so it is claimed to be the first green terminal in Indonesia (Banyuwangi Government, 2017).

Instead of using the technology of energy saver, the terminal uses passive architectural design which relates to the green concept. The terminal has the interior design which minimizes the usage of the partition to improve the air circulation and the sunlight. The installment of the fish ponds helps to keep the air pressure. Subsequently, the room temperature will be cool enough for the airport visitors even without the air conditioner (AC) (Banyuwangi Government, 2017).

The mayor of Banyuwangi emphasis the function of architectural design. By using the architectural approach, the public facility construction hasn't been only a usual project. The project will give the economic and socio-cultural values. The green airport terminal is a perfect example of the architectural implementation (Banyuwangi Government, 2017).

Compared with Ridwan Kamil of Bandung, the mayor of Bandung has a background as an architect, while the mayor of Banyuwangi isn't an architect. However, they both are using the help from the architects to work on the 
Graduate School, Universitas Gadjah Mada,August, 9 - 10, 2017 ,Yogyakarta-Indonesia

government plan. In Bandung, there is a program named " 1 village 1 architect". Ridwan opens a public participation in building Bandung city, as the participation of architects is one of his strategies. Despite having no similar program with Ridwan Kamil, Abdullah Azwar Anas has pinpointed his architectural program in the airport building (Yuhaemi, 2017).

There are three reasons about why the mayor of Banyuwangi prioritizes the architectural aspect. First, an iconic landmark is an output of an architect. The landmark will be an icon to boost the tourism of Banyuwangi. Second, there will a transfer of knowledge among the national architects to the local architects, so the special taste will be sustained as its best. Third, architects know how to fulfill the principles of the efficiency of the building. The air temperature system is one of the outputs of the principles (Banyuwangi Government, 2017).

Banyuwangi government uses the local wisdom to build the airport terminal. The airport adopts the concept of the traditional house of Osing tribe, the local tribe of Banyuwangi. Also, there is a pavilion to accommodate the families and relations who usually escort the passengers. The usage of a local wisdom of the smart city has been discussed by Effendi et al (2016), but in this context, it is applicable to the smart village (Banyuwangi Government, 2017).

By building the airport, Banyuwangi will be more accessible than before for the outside visitors. Also, Banyuwangi people can travel to other cities easier. The airport is a vital facility to improve the tourism of the Banyuwangi Regency (Banyuwangi Government, 2016b).

Taoyuan County in Taiwan is an example of the role of the international airport. The Taoyuan government initiates the aerotropolis concept to boost the economy and quality of living. The aerotropolis is a concept which uses an airport as a center of development (Nam \& Pardo, 2011).

We argue that the green terminal is a strategy of Banyuwangi government to mix the smart mobility and the smart environment, two out of six characteristics of a smart city. The smart mobility characteristic relates to transportation. The factors are local accessibility, national accessibility, international accessibility, availability of ICT-infrastructure, sustainable, innovative, and safe transport systems (Giffinger et al, 2007).

The smart environment characteristic relates to natural resources. The factors are attractivity of natural conditions, pollution, environmental protection, and sustainable resource management. By learning the factors of two characteristics of a smart city, the green airport of Banyuwangi can be considered as a smart city (village) implementation. We may call it as a smart airport (Giffinger et al, 2007).

Although the mayor has an initiative of the smart village, he can't do it by himself. The mayor needs a collaboration of the government, university, business, community, and media. The stakeholders which relate to this study are the government and the media. Without the role of mass media, the government's program won't be disseminated to the people of Banyuwangi (Effendi et al, 2016; Yuliarti et al, 2016). 
The 9 th International Graduate Students and Scholars' Conference in Indonesia (IGSSCI) SUSTAINING THE PLANET: A CALL FOR INTERDISCIPLINARY APPROACHES AND ENGAGEMENT

Graduate School, Universitas Gadjah Mada,August, 9 - 10, 2017 ,Yogyakarta-Indonesia

During the advancement of technology, the internet changes the people habit. The people tend to consume the online mass media instead of the printed media. This is the reason we choose the online mass media as our research focus about the smart village (Yuliarti et al, 2016).

\section{- Methodology}

To conduct the research, we modified the research strategies of Yuliarti and her colleagues (2016). We used the descriptive quantitative approach. Instead of using one online mass media vendor like the past research (Kompas), we chose the multiple mass media vendors.

There was a possibility that Kompas wasn't the most covering-media about a specific issue. But, we had our focus to the query search from Google News, a popular search engine which is used only to search news content online.

We searched the online news by using keywords "Bandara Hijau Blimbingsari Banyuwangi" (translation to English: "Green Airport Blimbingsari Banyuwangi"). We limited the search query to a year earlier and sorted it by its date. The research units were dated from July 2016 to June 2017.

We included the word "hijau" (green) because of a content reason, as the news using the keyword tend to focus on the uniqueness of the airport. We ignored the news which can't be accessed or contain no paragraph related to the profile of the green airport. Then, we copied the title and the body of texts and saved it into one document. Then, we manually counted the content analysis aspects.

This research used twelve aspects of the content analysis. The aspects are (1) the amount of the news, (2) the amount of "smart city" (and its synonyms) phrase appears, (3) the amount of "smart village" (and its synonyms) phrase appears, (4) the amount of "smart mobility" or "smart transportation" (and its synonyms) phrase appears, (5) the amount of "smart environment" (and its synonyms) phrase appears, (6) the amount of "mobility" or "transportation" (and its synonyms) phrase appears, (7) the amount of "environment" (and its synonyms) phrase appears, (8) the amount of "tourism" (and its synonyms) word appears, (9) the amount of "architecture" (and its synonyms) word appears, (10) the tone of the news, (11) the source of the news, (12) the name of the online mass media vendor.

\section{RESULT AND DISCUSSION}

The result of the content analysis can be accessed in Table 1 below:

Table 1 The content analysis of the aspect of the news. 
The 9 th International Graduate Students and Scholars' Conference in Indonesia (IGSSCI) SUSTAINING THE PLANET: A CALL FOR INTERDISCIPLINARY APPROACHES AND ENGAGEMENT Graduate School, Universitas Gadjah Mada,August, 9 - 10, 2017 ,Yogyakarta-Indonesia

\begin{tabular}{|c|c|c|c|}
\hline No & Aspect of the news & Frequency & $\%$ \\
\hline 1 & The amount of the news & 133 & 100 \\
\hline 2 & $\begin{array}{l}\text { The amount of "smart city" (and its synonyms) phrase } \\
\text { appears }\end{array}$ & 0 & 100 \\
\hline 3 & $\begin{array}{l}\text { The amount of "smart village" (and its synonyms) phrase } \\
\text { appears }\end{array}$ & 0 & 100 \\
\hline 4 & $\begin{array}{l}\text { The amount of "smart mobility" or "smart } \\
\text { transportation" (and its synonyms) phrase appears }\end{array}$ & 0 & 100 \\
\hline 5 & $\begin{array}{l}\text { The amount of "smart environment" (and its synonyms) } \\
\text { phrase appears }\end{array}$ & 0 & 100 \\
\hline 6 & $\begin{array}{l}\text { The amount of "mobility" or "transportation" (and its } \\
\text { synonyms) phrase appears }\end{array}$ & 21 & 100 \\
\hline 7 & $\begin{array}{l}\text { The amount of "environment" (and its synonyms) } \\
\text { phrase appears }\end{array}$ & 18 & 100 \\
\hline 8 & $\begin{array}{l}\text { The amount of "tourism" (and its synonyms) word } \\
\text { appears }\end{array}$ & 268 & 100 \\
\hline 9 & $\begin{array}{l}\text { The amount of "architecture" (and its synonyms) word } \\
\text { appears }\end{array}$ & 174 & 100 \\
\hline \multirow[t]{4}{*}{10} & The tone of the news & 133 & 100 \\
\hline & Positive & 115 & 86,47 \\
\hline & Neutral & 16 & 12,03 \\
\hline & Negative & 2 & 1,5 \\
\hline \multirow[t]{7}{*}{11} & The source of the news & 180 & 100 \\
\hline & The Regent of Banyuwangi & 99 & 55 \\
\hline & Indonesia's Minister for Transportation & 21 & 11,67 \\
\hline & Speaker of Indonesia People's Representative Council & 9 & 5 \\
\hline & Indonesia's Minister for Tourism & 7 & 3,89 \\
\hline & President Director of PT Angkasa Pura II & 6 & 3,33 \\
\hline & Others & 38 & 21,11 \\
\hline \multirow[t]{7}{*}{12} & The name of the online mass media vendors & 133 & 100 \\
\hline & Merdeka & 23 & 17,29 \\
\hline & Detik & 15 & 11,28 \\
\hline & Tribunnews & 14 & 10,53 \\
\hline & Beritajatim & 12 & 9,02 \\
\hline & Liputan6 & 8 & 6,02 \\
\hline & Others & 61 & 45,86 \\
\hline
\end{tabular}

- No Smart-Village -Related Topic

Table 1 shows that there are 133 news articles covering the green airport terminal of Blimbingsari during a year. Although having a wide range of media 
Graduate School, Universitas Gadjah Mada,August, 9 - 10, 2017 ,Yogyakarta-Indonesia

coverage, there is no special mention of the smart city or smart village. Even though, the design of the green airport leads to a smart city/village goal.

The smart village goal is a long journey, as there are six known characteristics to be fulfilled. However, the government needs to realize their journey will end to the implementation of a smart city/village (Giffinger et al, 2007).

Especially, by having the characteristics of the smart mobility and smart environment, Banyuwangi government may relate it to the "Smart Kampung" program. But, they don't aware that they can disseminate the smart village program as a bundle with the green airport campaign issue.

According to Effendi and his colleagues (2016), the smart village (city) is an output of the collaboration between the government, business, university, community and the media. So, we can't only focus our judgment to the government. Every part of the ecosystem must work on the smart village goal. The mass media should support the smart village initiation of the government.

According to the Table 1, the Regent of Banyuwangi, Abdullah Azwar Anas, is the main spokesperson of the issue. He is the main source of the issue since his messages have filled more than 50 percents of the news.

It means that the vision of the smart village must be attached with the government leader. If the leader doesn't understand the concept, it will be always questionable for the leader to claim the smart village implementation.

Since we conducted a research without doing an interview with the Regent, so we didn't study his projection. This media research pinpoints that the Regent hasn't related the green airport with the smart village concept.

It's interesting as we find out that two ministers of Indonesia have shown an awe about the green airport. The ministers of transportation and tourism, as a representative of the national executive government, contribute to the issue.

However, if we relate that two smart village characteristics, the Minister of Transportation is the most active one. The Minister of Environment and Forestry doesn't talk about the issue. In facts, the Minister of Transportation doesn't speak up about the smart mobility/transportation or the smart city/village.

In addition, Indonesia People's Representative Council, as a national legislative body, does the same. We notify the importance of the knowledge about the smart village concept in the future.

\section{- Media Talk About Tourism and Architecture}

While there is no honorable mention about smart city/village concept, the mass media coverage tends to use simple aspects like transportation and environment, since there are 21 words and 18 words respectively. But, both aspects aren't the important focus of the media. The tourism and architecture do.

The mass media know that the design of the green airport isn't only a common design. They use the word "architecture" 174 times. By acknowledging the word usage, we conclude that Banyuwangi government prioritizes the architecture of the building. 
The 9 th International Graduate Students and Scholars' Conference in Indonesia (IGSSCI) SUSTAINING THE PLANET: A CALL FOR INTERDISCIPLINARY APPROACHES AND ENGAGEMENT

Graduate School, Universitas Gadjah Mada,August, 9 - 10, 2017 ,Yogyakarta-Indonesia

The Banyuwangi government hires the architects to build a landmark, to sustain a special taste, and to accentuate the principle of efficiency. However, the architecture leads to the smart village goal, and the mass media don't mention it. If we compare Banyuwangi and Bandung, they both give priority in the architecture. It means, developing a smart city or a smart village needs a special taste (Yuhaemi, 2017; Banyuwangi Government, 2017).

The mass media tend to focus on the tourism. We find out the tourism word 268 times. This is the reason of the appearance of the Minister of Tourism. Instead of promoting smart village, the main goal of the online mass media publication is the tourism aspect. The government builds the green airport to increase the visibility of Banyuwangi among the tourists.

\section{- Positive News, Hidden Potency of Smart Village Vision}

The online mass media vendors talk highly about the green airport as we find out more than 80 percents of the positive news about it. We rarely find the neutral and negative news. We argue there are two reasons underlining it.

It means whether the green airport attracts mass media or the government is smart enough to collaborate with the media. The second reason implies that the media is a hidden potency of the smart village vision. However, this research points that the government hasn't used the potency to promote the smart village vision.

Our reason choosing multiple mass media vendors, instead of one vendor like Yuliarti and her colleagues (2016), is proven. Kompas, the mass media vendor of the prior research, doesn't belong to the top covering-media about the green airport issue.

There are four national mass media vendors and one provincial mass media vendor contribute to the media coverage. The national media vendors are Merdeka, Detik, Tribunnews, and Liputan6, while the only provincial mass media vendor is Berita Jatim.

Merdeka is the most active mass media vendor which covers the green airport issue. It's a possibility for the government to build a good relationship with the journalists of the mass media. Uniquely, the top two covering-media, Merdeka and Detik, are the pure online mass media, which don't serve the shapes of the traditional mass media.

By recognizing the potency of the positive news among the mass media, we agree that the media have a potential to be a vital collaborator of a smart village. However, the government of Banyuwangi hasn't maximized its potency. Moreover, the government hasn't related the green airport project as a stepping stone to the smart village implementation (Effendi et al, 2016).

\section{CONCLUSION}

From the discussion above, we can conclude that there is a high number of mass media coverage of the green airport. Multiple mass media vendors 
The 9 th International Graduate Students and Scholars' Conference in Indonesia (IGSSCI) SUSTAINING THE PLANET: A CALL FOR INTERDISCIPLINARY APPROACHES AND ENGAGEMENT

Graduate School, Universitas Gadjah Mada,August, 9 - 10, 2017 ,Yogyakarta-Indonesia

collaborate well to support the program of the government of Banyuwangi, especially the green airport. The intention of mass media vendors is clearly drawn with the majority of the positive news. However, the government hasn't shown any interest to make a direct explanation about the smart village vision within the green airport development.

The government may assume that it is too early to mention the green airport as a stepping stone of the smart village. In another side, the government may be the lack of knowledge about the smart village concept. In the future, the government must work even harder with the mass media to promote the smart village as the master plan of the regional development. The airport isn't only the green one, but the smart one.

The current focus of the mass media about the green airport is the tourism changer. They realize that the architecture varies, but they don't aim to the smart village idea. The green airport is the blend of a special touch of the mobility and the environment. The penta-helix ecosystem of the smart village must point it out.

We identify that the government leader is the vital actor to develop the smart village. The leader is the main source of the news, so he must comprehend the grand design of the smart village. However, there is a critical question. The time files and the leader changes, how does the continuity of the vision?

\section{ACKNOWLEDGEMENTS}

This is self-funding research. We didn't receive any specific grant from any funding agency. So, there is no potential conflict of interest.

\section{References}

Banyuwangi Government. 2016a. Smart Kampung Banyuwangi Gerakkan Ekonomi Lokal. Available at: http://www.banyuwangikab.go.id/berita-daerah/smartkampung-banyuwangi-gerakkan-ekonomi-lokal.html

Banyuwangi Government. 2016b. Menhub: Banyuwangi Jeli Garap Bandara sebagai Ikon Pariwisata. Available at: http://banyuwangikab.go.id/beritadaerah/menhub-banyuwangi-jeli-garap-bandara-sebagai-ikonpariwisata.html

Banyuwangi Government. 2017. Pertama di Indonesia, Terminal Hijau Bandara Banyuwangi Siap Beroperasi. Available at: http://banyuwangikab.go.id/berita-daerah/pertama-di-indonesia-terminalhijau-bandara-banyuwangi-siap-beroperasi.html

Effendi, D., Syukri, F., Subiyanto, A. F., \& Utdityasan, R. N. (2016, July). Smart city Nusantara development through the application of Penta Helix model (A practical study to develop smart city based on local wisdom). In ICT For Smart Society (ICISS), 2016 International Conference (pp. 80-85). IEEE. 
The 9 th International Graduate Students and Scholars' Conference in Indonesia (IGSSCI) SUSTAINING THE PLANET: A CALL FOR INTERDISCIPLINARY APPROACHES AND ENGAGEMENT Graduate School, Universitas Gadjah Mada,August, 9 - 10, 2017 ,Yogyakarta-Indonesia

Giffinger, R., Fertner, C., Kramar, H., Kalasek, R., Pichler-Milanovic, N., \& Meijers, E. (2007). Smart cities - Ranking of European medium-sized cities (Report). Vienna University of Technology (Retrieved from http://www.smartcities.eu/download/smart_cities_final_report.pdf).

Intelligent Community Forum. 2017. List of All Intelligent Communities, Available at: http://www.intelligentcommunity.org/intelligent_communities_list, accessed May 2017.

Nam, T., \& Pardo, T. A. (2011, June). Conceptualizing smart city with dimensions of technology, people, and institutions. In Proceedings of the 12th annual international digital government research conference: digital government innovation in challenging times (pp. 282-291).

Sanjaya, A., Krisna, S.A., Mursito, T. B., \& Supriyadi. (2017, July). Research Trends of Smart City in Indonesia: Where Do We Go from Here? In International Conference on Education and Social Sciences (ICESS), 2017 (Upcoming event).

Yuhaemi, Y. 2017. Ridwan Kamil, Wali Kota Bandung yang Libatkan Banyak Partisipasi Publik. Available at: http://news.okezone.com/read/2017/06/07/525/1709883/ridwan-kamilwali-kota-bandung-yang-libatkan-banyak-partisipasi-publik

Yuliarti, M. S., Nurhaeni, I. D. A., \& Nugroho, R. A. (2016, July). Smart City and Media (When Kompas Online Talks about Smart Cities in Indonesia). In International Conference on Public Management (ICPM) 2016 (pp. 406-408). 